\title{
Innovation, knowledge creation and technology policy in Europe
}

Citation for published version (APA):

Soete, L. L. G., \& ter Weel, B. J. (1999). Innovation, knowledge creation and technology policy in Europe. MERIT, Maastricht Economic Research Institute on Innovation and Technology. MERIT Research Memoranda No. 001 https://doi.org/10.26481/umamer.1999001

Document status and date:

Published: 01/01/1999

DOI:

10.26481/umamer.1999001

Document Version:

Publisher's PDF, also known as Version of record

\section{Please check the document version of this publication:}

- A submitted manuscript is the version of the article upon submission and before peer-review. There can be important differences between the submitted version and the official published version of record.

People interested in the research are advised to contact the author for the final version of the publication, or visit the DOI to the publisher's website.

- The final author version and the galley proof are versions of the publication after peer review.

- The final published version features the final layout of the paper including the volume, issue and page numbers.

Link to publication

\footnotetext{
General rights rights.

- You may freely distribute the URL identifying the publication in the public portal. please follow below link for the End User Agreement:

www.umlib.nl/taverne-license

Take down policy

If you believe that this document breaches copyright please contact us at:

repository@maastrichtuniversity.nl

providing details and we will investigate your claim.
}

Copyright and moral rights for the publications made accessible in the public portal are retained by the authors and/or other copyright owners and it is a condition of accessing publications that users recognise and abide by the legal requirements associated with these

- Users may download and print one copy of any publication from the public portal for the purpose of private study or research.

- You may not further distribute the material or use it for any profit-making activity or commercial gain

If the publication is distributed under the terms of Article $25 \mathrm{fa}$ of the Dutch Copyright Act, indicated by the "Taverne" license above, 


\title{
Innovation, knowledge creation and technology policy in Europe
}

\author{
Luc Soete ${ }^{\mathrm{a}}$, Bas ter Weel ${ }^{\mathrm{b}, *}$ \\ ${ }^{a}$ Faculty of Economics and Business Administration and Maastricht Economic Research Institute on Innovation \\ and Technology (MERIT), Maastricht University. \\ ${ }^{b}$ Maastricht Economic Research Institute on Innovation and Technology (MERIT), Maastricht University.
}

\begin{abstract}
This paper discusses the position of the European Union in the world economy by focussing on innovation, knowledge creation and technology policy. First, we explore and analyse the concept of knowledge and its application in a modern Schumpeterian framework. Second, we address some new insights in the diffusion and other properties of knowledge. Third, we focus on knowledge spillovers by investigating Dutch manufacturing. Thereafter, we examine technology policy.
\end{abstract}

Keywords: Innovation, Knowledge, Technology, Policy

" Corresponding author: B. J. ter Weel, MERIT, Maastricht University, P.O. Box 616, 6200 MD, Maastricht; Tel: 0031-43-3883873; Fax: 0031-43-3216518; E-mail: b.terweel@ merit.unimaas.nl.

Helpful comments by Hugo Hollanders are gratefully acknowledged. 


\section{Introduction}

Science and Technology (S\&T) and more recently formalized industrial Research and Development $(\mathrm{R} \& \mathrm{D})$ has been the subject of public interest and support for centuries. The acceptance of a utilitarian argument for the public support of basic scientific research actually predates the Industrial Revolution itself. It is impossible to review in this article the innumerable contributions which have been made over the last decade on both the raison d'être and intrinsic limits of public support for S\&T and R\&D in particular. However, there is little doubt that some broad trends can be identified, not in the least because of the development of new, what could be called 'post national', European institutions governing S\&T and R\&D support in particular.

At the same time a significant shift in the purpose and nature of such policies has occurred. From an early trend towards centralized public support for 'big science' areas often considered of strategic importance: military research, (atomic) energy research, aeronautics, support shifted within the framework of the notion of so-called 'pre-competitive' research support to new sunrise sectors such as microelectronics. More recently, it could be argued that a shift occurred in the nature of the public support away from technology push support towards more demand pull programs, with greater acceptance of the crucial role of users and the intrinsic recognition that technical success does not necessarily imply economic success. The European Commission's recent Green Book on Innovation provides probably the most explicit recognition of the need for this shift towards innovation policies describing Europe's failure in developing new products and new technology based firms as a European technology paradox: excellence and strength in basic and fundamental research yet failure to translate this in commercial excellence and success. ${ }^{1}$

In this short article we cannot go into much detail into the development and formal organization of European technology policy. There is now a voluminous literature on this subject, not in the least from the European Commission itself. ${ }^{2}$ We limit ourselves here to a brief overview in a first section to some of the most significant features and aspects of this new, post-national innovation

\footnotetext{
${ }^{1}$ See EU (1996).

${ }^{2}$ See the EU report on S\&T indicators, EU (1997).
} 
system. The focus of our paper is rather on the more fundamental shift in both academic and policy making circles in the direction of recognizing the crucial role of the broader notion of knowledge creation and diffusion for economic growth and international competitiveness. This 'new' economics of knowledge creation and diffusion is the focal point of section 2 of the paper. It implies, a growing recognition that technical change is in our current highly developed, open societies a complex dynamic process that involves many social and economic factors and a wide range of individuals, institutions and firms. The capacity of an economy to derive competitive advantages from technical change and innovation is in the end dependent on the dynamic efficiency with which firms and institutions can diffuse, adapt, and apply information and knowledge.

From this perspective the current debate on science, technology and innovation policy will have to recognize to a much larger extent some of the new structural features of what is now largely recognized as the trend of our societies towards a knowledge based economy. This renewed recognition of the importance of 'knowledge' is based as we argue in section 2 on three factors. It raises some fundamental new policy challenges which can in our view, and as argued, best be answered using more explicitly some Schumpeterian concepts based on both contributions from New Growth Theory (NGT) and as well as on more appreciative, structural descriptions of sectoral technological developments represented for instance in Richard Nelson's recent Tinbergen lecture. ${ }^{3}$

In Section 3, we then turn to some econometric facts for the Netherlands by first analyzing knowledge spillovers and second by investigating the internalization of these spillovers, and in particular the contribution of European spillovers. The latter are of particular importance given the purpose of European technology policies to provide room for economies of scope and scale in S\&T and R\&D in particular. Moreover, the search for internalization of R\&D efforts point towards the need of alternative modes of institutional development and learning, not in the least at the international, European level. In this regard we follow the contributions by Weder and Grubel (1993) and Romer (1993), evaluating the institutional technology environment within the

\footnotetext{
3 See Nelson (1999).
} 
European Union (EU) in which there is both scope for the internalization of R\&D and the stimulation of cross-border, joint R\&D efforts.

We conclude by proposing a new framework for European technology policy.

\section{The emergence of an European post-national S\&T system}

Both the early literature on NSIs and the more recent interpretation of the concept by David and Foray (1995) bring to the forefront the wide diversity of national policy instruments in the S\&T area. While some of these might have been characterized by general notions that were 'mission' or 'diffusion' oriented (e.g. Ergas (1987)), recent literature suggests that such understandings hide much of the institutional nature of these systems and hence do not lead the policy debate very far. The notion of some internationally valid 'best practice' institutional mechanism in the S\&T area seems from this perspective not justified.

This raises some fundamental questions about the convergence of the various national S\&T systems, and the possibilities for the emergence of an 'European S\&T system'. The wide diversity across the EU member states in the amount of resources devoted to research, the structure of those resources, the importance of industry/university relationships and the institutional organisational set-up of government support ${ }^{4}$ warrant a much closer look at the S\&T policies followed in the various EU member states. The latter are to a large extent shaped by a long and in some countries rich history of S\&T institutions and different administrative traditions. Despite the variety in institutional structures governing S\&T policy, there is nevertheless evidence for convergence in the objectives of such policies and their implementation mechanisms, if only because most countries appear to be confronted with similar budgetary pressures and concerns.

EU integration has by now a history of more than forty years. It has led to the development of a

\footnotetext{
${ }^{4}$ Both at central and federal and regional levels.
} 
number of simultaneous or lagging convergence processes, creating a post-national 'layer' of activities for national firms and governments. Johnson and Gregersen (1995) define European integration as "a process towards a coherent institutional setup for production, trade and innovation within Europe." They identify four interrelated types of economic integration in a matrix. These types are (i) formal and (ii) informal institutional arrangements between political actors, and (iii) formal and (iv) informal institutional arrangements between economic actors. We concentrate on type (i), formal EU institutions, and type (iv), changes in the informal institutional set-up and communication pattern among private agents, e.g., through networking. ${ }^{5}$

The development of European integration from the European Steel and Coal Community (ESCC) to the EU has led to the setting up of a number of original post-national institutions which have contributed significantly to shaping the innovation process in the different European member states. These institutions can be called 'post-national' for two reasons. First, they have created stable links between the main actors and existing organizations which have contributed to the fabric of NSIs and have been supported by specific new organizations; and second, they have not replaced national institutions which continue to determine the specifics of NSIs.

Despite their wide and diverse coverage, most institutions created over the last forty years within the framework of European integration can be related directly to the three essential components of knowledge infrastructure: Research and technological development (RTD), innovation transfer, and training and education. Furthermore, despite the impression of a relatively recent emergence of such institutions, they can be traced back to the early failure to implement, under the Euratom Treaty, an European division of labour of nuclear research. Hence these institutions have combined elements of federalism (where sovereignty and the regulation of human interaction has been displaced at a supranational level) with elements of intergovernmental cooperation (where national institutions are interlinked while remaining truly autonomous). Thus, in Europe the institutional building process has been the result of very diverse social, political, and economic processes which explains its heterogeneity and also its specific character.

\footnotetext{
${ }^{5}$ See also Caracostas and Soete (1997) on the tripartite discussion of cross-border institution building in Europe.
} 
We have, in other words, a market tending towards unification, regulated by well-defined competition and trade policy rules with emerging (research, innovation, regional development) structural policy institutions. This emerging post-national system of innovation produces, and is produced by, specific post-national institutions that are both formal (treaties, community programs, and other European schemes) and informal (networks, common habits, and norms).

One can assume that the core of a system of innovation at the European level is made of those organizations and institutions regulating the creation, diffusion and use of knowledge and knowhow in cooperation across member states' boundaries; i.e., organizations and institutions dedicated to research, innovation, and education and training. Other structural policy institutions, although they often include a very significant innovation component, are not considered here because they are not primarily designed for contributing to the emergence of a post-national innovation space but rather for strengthening NSIs in less favoured countries and in specific regions.

The Treaty of the EU defines the rules governing research, innovation, and education/training institutions. In the field of research, Title XV defines the objectives, the actions that can be carried out, the decision-making procedures, and the implementation mechanisms. Innovation is only quoted in the title concerning industry where it is said that the Community aims at favouring a better exploitation of the industrial potential of innovation policies. Finally, a distinction is made in the treaty between education for which no real policy is mentioned (only Community action) and training which is the subject of a true EC policy.

Research institutions have a longer history. They promote transnational cooperation in the field of the production of knowledge and know-how and its diffusion across Europe. The Fourth Framework Program (1994-1998) and related specific programs are now key components together with competition rules governing state aids and cooperation agreements between firms. ${ }^{6}$

Innovation policy institutions, if conceived in a restrictive manner as specific formal rules

\footnotetext{
${ }^{6}$ See the European Commission's (1994) Report for a description of EU research policy
} 
influencing the innovation capacity of firms beyond $R \& D$ and technological demonstration, do not exist at the EU level. Support programs for innovation and technology transfer, however, can be considered as quasi-institutions in so far as they have influenced the behaviour of specific actors in the innovation process, i.e. the wider category of intermediaries working in the field of technology transfer and application in SMEs. The Strategic Program for Innovation and Technology Transfer (SPRINT) is an embryo of such innovation policy institutions. From 1989 to 1994 it contributed to the development of innovation support services for SMEs, to the demonstration of intra-Community technology transfer and technology acquisition, and to the improvement of a common European awareness of the innovation process.

Education and training institutions, although they were partly (for training only) foreseen by the EEC Treaty in the provisions related to the European Social Fund, have been created by the Treaty of the EU. The new rules formalize previous ad hoc experimentation through Community programs. For example, the experience of COMETT is very interesting from the point of view of nascent training institutions at the European level.

Up to now, it could be argued that the European institutions have been primarily developed in support of an emerging 'knowledge-producing' national European innovation system. In doing so they have focussed on the realisation of essential complementarities with respect to more traditional EU economies of scale or harmonisation aims: (i) the Single Market, (ii) liberalisation, transparency and establishment of common competition rules, (iii) targeting of strategic industries considered crucial for competitiveness, and (iv) support for R\&D activities of large EU multinationals. As we will argue in the next section, the new, fundamental policy challenge for Europe could be viewed as the enhancement and development of the 'distributive' innovation capacity at an European level: the creation and strengthening of an European institutional set up based on a more 'diversity-connectivity' network approach to the various existing poles in Europe of technological specialisation and expertise. How such a system could interact with national, regional and local systems of innovation so as to interconnect local competences; how to support new ventures, new businesses and new modes of organisation and learning are examples of issues we come back to in our conclusions. 


\section{The 'new' economics of innovation and knowledge creation}

The concept of technological progress, through innovating activities and knowledge creation, as the main engine for economic growth, is not a new one in economics. Its importance was already stressed and at the core of economic thinking from the late eighteenth century on. We only have to consider the dominant role given to technological progress by classical economists such as Karl Marx or this century by Joseph Schumpeter, to realise that economists have always been aware of the crucial importance of innovation and knowledge accumulation for long-term growth. ${ }^{7}$ However, three features seem to be the basis of the current, renewed importance given to knowledge for economic growth and welfare.

First, the economic profession has started to recognize the fact that knowledge accumulation can be analysed like the accumulation of any other capital good. That one can apply economic principles to the production and exchange of knowledge; that it is intrinsically endogenous to the economic and the social system and is not an external, black box factor, not to be opened except by scientists and engineers. Hence, while knowledge has some specific features of its own, it can be produced and used in the production of other goods, even in the production of itself, like any other capital good that is used as an input in the production process. It also can be stored and will be subject to depreciation, when skills deteriorate or people no longer use particular knowledge and forget about it. It might even become obsolete, when new knowledge supersedes and renders it worthless.

However, there are some fundamental differences with traditional material capital goods. First, and foremost, the production of knowledge will not take the form of a physical piece of equipment, but is generally embedded in some specific blueprint form (a patent, an artefact, a design, a software program, a manuscript, a composition) or in human beings or even in organisations. In each of these cases there will be so-called positive externalities: the knowledge embodied in such blueprints, people or organisations cannot be fully appropriated, it will with

\footnotetext{
${ }^{7}$ Recently Schumpeter's insights have been picked up and formalized by scholars in the field of (endogenous) growth models. Examples are Segerstrom, Anant and Dinopoulos (1990), Romer (1990), Grossman and Helpman (1991), Aghion and Howitt (1988) and (1992) and Caballero and Jaffé (1993). An excellent overview of these modern Schumpeterian approaches is given in Aghion and Howitt (1998).
} 
little cost to the knowledge creator flow away to other firms or to the public knowledge stock. Knowledge is, from this perspective, a non-rival good. It can be shared by many people without diminishing in any way the amount available to any one of them. Of course there are costs in acquiring knowledge; a research department working on innovative projects is certainly not cheap. Therefore, a current central theme coming to the surface in economic theory is what is referred to as information asymmetry: the person wanting to buy something from someone who knows more about it, obviously suffers from an asymmetry in information.

This explains why markets for the exchange of knowledge are rare and why most firms have preferred to carry out innovative activities 'inhouse' rather than have it contracted out or licensed; a lot of the knowledge created must be appropriated in order to prevent direct spillover effects to competitors from happening. However, once knowledge is available at no single cost, no firm has an incentive to acquire knowledge at any cost. It also provides a rationale for policies focussing on the importance of investment in knowledge accumulation, as we discuss later on. Such investments are likely to have high so-called social rates of return -- because of its nonrivalry properties and the easiness with respect to spillover effects -- often much higher than the private rate of return. Hence, investment in knowledge cannot be simply left to a competitive market environment.

Second, the growing economic and policy consensus on the importance of knowledge for industrial competitiveness is closely related to the emergence of a cluster of new information and communication technologies (ICTs), which have resulted in a dramatic decline in the price of information processing; in a technological driven digital convergence between communication and computer technology; and last, but not least, a rapid growth in international electronic networking.

ICTs are in the real sense of the word an information technology (IT), the essence of which consists of the increased memorisation and storage, speed, manipulation and interpretation of data and information. In short, it is what has been characterized as the codification of information and knowledge. As a consequence, IT makes codified knowledge, data and information much more accessible than before to all sectors and agents in the economy linked to information 
networks or with the knowledge how to access such networks. This is not to deny the importance of tacit knowledge; on the contrary, as more and more knowledge becomes codifiable, the remaining non-codifiable part becomes even more crucial.

Thus, the ability to codify relevant knowledge in creative ways acquires strategic value and will affect competitiveness at all levels. Network access as well as the competence to sort out the relevant information and to use it for economic purposes become of critical importance for performance and income distribution. Specific skills, referring to the use of information, become of strategic importance. More routine skills, by contrast, might become totally codifiable and their importance might be reduced dramatically. ${ }^{8}$ While the idea of ICTs as a skill-biased technical change, does not consequently capture very well the complexities of the accompanying required de- and reskilling processes, it points nevertheless to the importance of the distributional impact of ICTs.

As a consequence of the increased potential for international codification and transferability, ICTs can be considered as the first truly global technology. The possibility of ICTs to codify information and knowledge over both distance and time, brings about more global access. Knowledge, including economic knowledge becomes to some extent globally available. While the local capacities to use or have the competence to access such knowledge will vary widely, the access potential is there. ICTs, in other words, brings to the forefront the enormous potential for catching-up, based upon cost advantages and economic transparency of (dis)advantages, while stressing at the same time the crucial tacit and other competence elements in the capacity to access international codified knowledge. For technologically leading countries or firms, this implies increasing erosion of monopoly rents associated with innovation and shortening of product life cycles. We observe less and less appropriability due to global access to ICTs, which might lead to less innovative activities as the self-reinforcing positive loop from successful innovation to increased innovative activities becomes shorter and more competitive due to this globalization. Research efforts may not be profitable anymore in this setting, when we analyse a single firm. However, associations, conglomerates or industry clusters might be able to

\footnotetext{
${ }^{8}$ In contrast, relatively simple human tasks (gardening) might never become codifiable.
} 
internalize these externalities, as we will show in the next section.

Furthermore, globalization does not merely represent an extension of opportunities from the national to the EU or global level. It also generates new constraints. Applications of information related technologies at the national level will need to be fully compatible with international trends to avoid the risk of cut-off from vital economic flows. Progress in the ability of firms to customize production will paradoxically multiply the number of mini-markets within the global market, and thus require new marketing skills and new types of interaction with customers. The security of the new world networks acquires strategic importance. Beyond the new legal framework that is required, the operation of international information flows in real time will need to be based on relations of trust between partners that will directly affect the distribution of tasks within firms and between firms. This might reduce the ability of each economic actor to innovate single-handedly in certain key areas, and stresses the important (future) role of strong technology clusters and government investment in knowledge.

Third, we would argue that the perception of the nature of innovation processes has also changed significantly over the last decade. Broadly speaking, innovation capability is seen less in terms of the ability to discover new technological principles, and more in terms of the ability to exploit systematically the effects produced by new combinations and use of pieces in the existing stock of knowledge. This new model implies to some extent more routine use of a technological base allowing innovation without the need for leaps in technology. It requires systematic access to the state-of-the-art technologies; each industry must introduce procedures for the dissemination of information regarding the stock of technologies available, so that individual innovators can draw upon the work of other innovators. To stimulate this trend, industry clusters of innovation or NSIs can be useful in combining and exploring existing knowledge into new products and/or technology standards and skills to secure future economic growth. This mode of knowledge generation -- based on the recombination and re-use of known practices -- raises also much more information-search problems and must confront the problems of the impediments to accessing the existing stock of information that are created by intellectual property right laws. ${ }^{9}$

\footnotetext{
${ }^{9}$ Problems raised by the increasing costs induced by the functions of storing, retrieving, evaluating and using knowledge.
} 
The S\&T system is, in other words, shifting towards a more complex socially distributed structure of knowledge production activities, involving in particular a great diversity of organizations having an explicit goal of producing knowledge (learning entities). The old system by contrast, was based on a simple dichotomy between deliberate learning and knowledge generation (R\&D laboratories and universities) and activities of production and consumption where the motivation for acting was not to acquire new knowledge but rather to produce or use effective outputs. The collapse (or partial collapse) of this dichotomy conducts to a proliferation of new places having the explicit goal of producing knowledge and undertaking deliberate research activities, which may not be readily observable but nevertheless essential to sustain innovative activities in a global environment.

This shift in perception brings in many ways to the forefront the importance of the distinction made by Schumpeter between two different technological regimes through which the innovative process, which enhances, induces and possibly accelerates economic growth, takes place. ${ }^{10}$

The first approach -- in the literature defined as the Schumpeter Mark I regime -- lays emphasis on the innovating entrepreneur who observes possibilities for the introduction of new products, and subsequently enters in this so-called niche of some market. By entering in this niche, the entrepreneur challenges the incumbent firm and hence the existing leading-edge technology and/or product. This process of quality improving or vertical innovation, that itself results from (uncertain) research initiatives, is called creative destruction. The notion of creative destruction has by definition the natural property that new inventions make the leading-edge technology and/or products obsolete, which more or less forces the incumbent firm to withdraw from the market. This market, in a Schumpeter Mark I regime, is characterized by many small firms who use the 'public basin' of existing knowledge or the general and easy accessable knowledge stock to innovate, while the knowledge created by their invention is added to this public basin and used by the next entrepreneur to challenge the incumbent, and so on. This description of affairs

\footnotetext{
${ }^{10}$ See Nelson and Winter (1982) and Winter (1984) for influential contributions with respect to the modelling of Schumpeterian technological regimes. The former is primarily concerned with the basic mechanics of Schumpeterian competition, particularly innovative and imitative strategies and their influence on the evolution of industrial structures, while the latter extended this model with endogenous entry and adaptive R\&D strategies of firms, which emphasized the main characteristics of Schumpeter Mark I and Schumpeter Mark II technological regimes.
} 
contrasts the other regime described by Schumpeter.

Schumpeter's second approach -- which is labelled Schumpeter Mark II regime -- considers innovative activities conducted by large and established firms. The process of innovative activities of these firms is often called creative accumulation, because when large firms successfully innovate, they often appropriate the main part of their invention (instead of being forced to add their newly acquired knowledge to the public basin), which leads to a strong positive feedback loop from innovation to increased $R \& D$ activities. This self-reinforcing process is mainly due to the high level of appropriability because firms prevent their innovation from imitation and hence appropriate the profits from an innovation to the largest extent possible. Notable devices in this regard are patents, secrecy, lead times, costs and time required for duplication, learning curve effects, superior sales efforts, and differential technical efficiency due to scale economies.

Another argument in favour of the positive feedback loop is the high degree of cumulativeness. In this respect cumulativeness refers to the extent to which innovations are serially correlated and it clearly depends on whether technological progress depends and moves on with the currently applied technology. Moreover, cumulativeness is a good example of learning by doing. Thus, whereas the incumbent entrepreneur in a Schumpeter Mark I regime is forced to withdraw in case of a new leading-edge technology, the incumbent firm in a Schumpeter Mark II can build on past experience. Finally, the Schumpeter Mark II regime improves the market position of the innovating firm and hence creative accumulation leads to high degrees of concentration, whereas creative destruction leads to a competitive market environment. ${ }^{11}$

\footnotetext{
${ }^{11}$ In the literature the differences between the two Schumpeterian regimes are discussed in terms of four factors: (i) opportunity; (ii) appropriability; (iii) cumulativeness of innovative activities; and (iv) the nature of knowledge. Given these differences, industries are likely to differ with respect to their dynamic and structural properties, what would be termed 'technological regimes'. See e.g. Malerba and Orsenigo (1993) for an elaboration. Oltra (1998) shows in this respect that the nature of knowledge and the characteristics of the technological environment determine the patterns of innovative activities and the evolution of industrial structure. Van Dijk (1998) tests whether differences in dynamic and structural properties actually exist, by using firm-level data on the manufacturing sector in the Netherlands. He observes that these properties of the industries are strongly related to the underlying technological regimes.
} 


\section{Figure 1}

A Schematic Presentation of Economic Activities in a Schumpeterian Setting

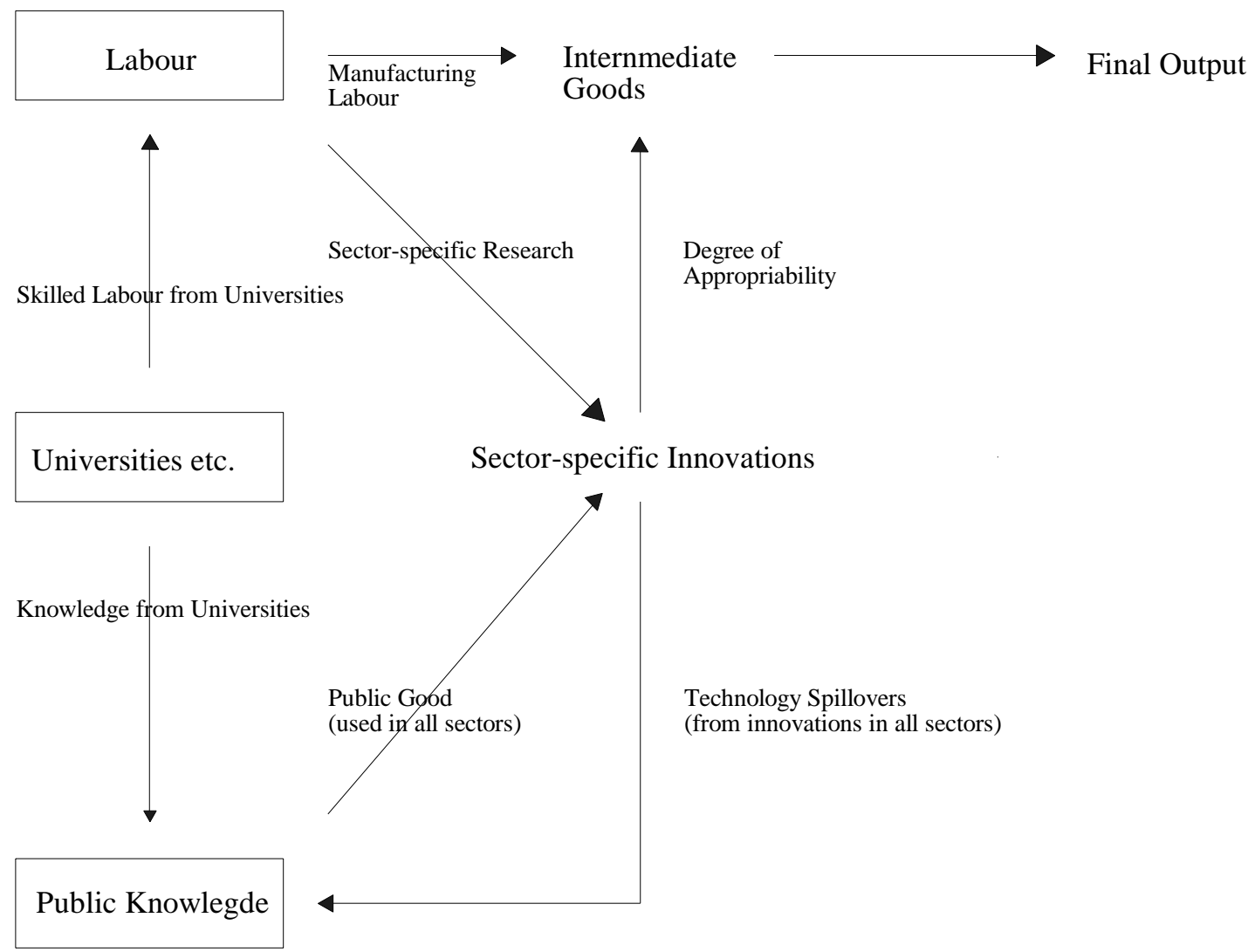

Source: Adapted from Aghion and Howitt (1998)

Figure 1 gives us a basic schematic presentation of economic activities in a Schumpeterian environment. ${ }^{12}$ This figure shows us that a firm possibly splits its labour force in a research department and a manufacturing division. In the research department, workers are supposed to invent new products and/or technology standards, while workers in the manufacturing division produce intermediate goods, that are used to create the final output of the particular firm.

Sector-specific innovations are induced and occur because of the effort of the firm's research department on the one hand, and public knowledge from the public basin on the other hand. Once

\footnotetext{
${ }^{12}$ For simplicity we omit capital.
} 
a firm has invented a new product and/or technology standard, it depends on the degree of appropriability whether the knowledge used to innovate spills over to the public knowledge basin or not. In the case of a Schumpeter Mark I regime all benefits from the innovation spill over to the public knowledge basin. It is therefore that firms in this regime have no incentive to innovate, once they are at the leading-edge; the degree of appropriability is (almost) zero. In a Schumpeter Mark II regime, the degree of appropriability can be fairly high. Large firms often patent their innovations, while their innovations take much time and large effort to duplicate and/or imitate. Hence, direct technology spillovers are not to be expected from large firms to the extent they are observed in a Schumpeter Mark I regime.

Public knowledge is also enhanced by research performed at universities and other research institutes. Their output in the form of knowledge is often published in scientific journals or transmitted by channels such as conferences. This improves the overall knowledge stock in the economy and induces innovative activities. Moreover, universities educate individuals that enter sooner or later labour force. By means of education the labour force becomes more productive because individuals obtain a higher skill level. These skills can be applied in both the manufacturing division and the research department of the firm. By employing skilled individuals, labour productivity levels are supposed and expected to increase. This in turn leads to higher levels of innovative activities in the research department, on the one hand, and higher levels production in the manufacturing division, on the other. Of course, these skilled individuals can also be employed at the universities themselves. Employing them at universities leads to a direct positive effect on the stock of public knowledge, while employing skilled individuals at firms or in the business sector leads to possible indirect effects on the stock of public knowledge through the effort put in innovative activities at the firm level. ${ }^{13}$

\footnotetext{
${ }^{13}$ The term skill can hardly be caught in a simple straightforward definition. We are therefore not concerned with the exact meaning and application but just divide the workforce in skilled and unskilled labour. For exact definitions see Wolff (1995) and OECD (1996).
} 


\section{National, European and international knowledge spillovers}

It will be clear from the previous analysis that the creation of knowledge will be characterized by significant spillovers: the knowledge created will not be fully appropriated and will flow to other firms in the same sector, to other using sectors, and of course to other countries. From a Schumpeterian perspective such spillovers have often been identified with the notion of clusters of innovations, including the follow-up innovations made during the diffusion period. Elsewhere, it is argued that the clustering of such radical innovations can be linked to the rapid growth of new industries and, in the extreme case, can even provide ingredients of an upswing in overall economic growth. ${ }^{14}$ At the more formal level, econometric studies have established how such R\&D spillovers play a significant role in explaining economic growth. ${ }^{15}$

In this regard, spillovers from one sector or country to the other, generated in the process of performing R\&D, have gained much attention recently. ${ }^{16}$ Griliches (1992) defines in his analysis, on the one hand, rent spillovers generated by international trade and, on the other hand, knowledge spillovers generated by blue prints like patent information, scientific literature and imitation. Particularly the latter is of main importance for our analysis here. In the remainder of this section we first explore and stress the importance of the impact of knowledge spillovers on labour productivity. Second, we turn to the analysis of internalizing R\&D efforts by means of associations, conglomerates and industry clusters.

\footnotetext{
${ }^{14}$ See e.g. Soete and Turner (1984) and Freeman and Soete (1987).

${ }^{15}$ See e.g. recent studies by Coe and Helpman (1995), Coe, Helpman and Hoffmaister (1997) and Engelbrecht (1997). Coe and Helpman (1995) study international R\&D spillovers in a long-run equilibrium model and conclude that R\&D spillovers play a prominent role in the explanation of productivity growth and productivity convergence across countries. This long-run equilibrium model is an useful tool to investigate the extent to which a country's productivity level depends on domestic and foreign R\&D and foreign R\&D capital stocks. Bernstein and Mohnen (1991) have shown that it is important to account for temporary deviations from long-run equilibrium growth paths in measuring productivity growth because simply assuming that producers are always employing their long-run equilibrium capital stock can lead to biases in measured productivity growth. Bernstein and Mohnen (1998) account for these deviations from long-run equilibrium by using adjustment costs. Their results are in line with other studies associated with domestic R\&D spillovers - see Griliches (1992), as well as the social rates obtained by Coe and Helpman (1995) in a multi-country context.
}

${ }^{16}$ See e.g. Griliches (1992), Coe and Helpman (1995), Van Meijl (1995) and Verspagen (1995). 
We use the so-called 'technology flow matrix', developed in Verspagen (1997a) and (1997b), to describe knowledge flows from the knowledge producing to the knowledge consuming sectors. As an example, we explore the Dutch manufacturing sector from 1973 to 1995 (the latest year for which data are available). The purpose of this analysis is to show how knowledge created in one particular sector -- either domestic or foreign -- is applied and used in the Dutch economy. This analysis gives us both a clear picture of the knowledge flows within the Dutch manufacturing sector and the dimension or degree to which imported knowledge is having an impact.

The analysis is built on the following simple Cobb-Douglas production functions

$$
Y_{j, t}=A_{j} K_{j, t}{ }^{\alpha} L_{j, t}{ }^{\beta} R D_{j, t}{ }^{\rho} \operatorname{IRD} D_{j, t}{ }^{\delta} \operatorname{IRE} U_{j, t}{ }^{\epsilon} \operatorname{IROT} T_{j, t}{ }^{\sigma}
$$

and

$$
Y_{j, t}=A_{j} K_{j, t}^{\alpha} L_{j, t}^{\beta} R D_{j, t}{ }^{\rho} \operatorname{IR} D_{j, t}{ }^{\delta} I R F_{j, t}{ }^{\phi}
$$

where subscript $j$ refers to sector $j$ and $t$ is the time indicator. The data used refer all to manufacturing sectors and are taken from the OECD STAN, ANBERD and BITRA databases. ${ }^{17}$ $Y$ is defined as value added generated in the production process, $A$ is a scale variable, $K$ is the capital stock, $L$ the amount of labour used in the production process, $R D$ the knowledge created and applied in sector $j, I R D$ is the knowledge available from the public knowledge basin in the Netherlands, IREU is the knowledge available from the public knowledge basin in the EU, IROT from the rest of the world and IRF is the sum of IREU and IROT, i.e. indirect knowledge

\footnotetext{
${ }^{17}$ The following twenty two sectors are included in our analysis (ISIC code between brackets): Food, beverages, tobacco (31), Textiles, leather, footwear (32), Wood and wooden products (33), Printing and publishing (34), Chemicals excl. pharmaceuticals $(351+352-3522)$, Pharmaceuticals (3522), Refined oil and related products $(353+354)$, Rubber and plastic products $(355+356)$, Glass, stone and clay (36), Ferrous basic metals (371), Nonferrous basic metals (372), Simple metal products (381), Machinery (382-3825), Computers and office machines (3825), Electrical goods (383-3832), Radio, TV, telecommunication equipment and electronic components (3832), Ships and boats (3841), Automobiles (3843), Aerospace (3845), Other transport equipment (384-3841-3843-3845), Instruments (385) and Other manufacturing (39).
} 
spillovers from abroad. The parameters $\alpha, \beta, \rho, \delta, \phi, \epsilon, \sigma$ are the elasticities with respect to each of them.

The capital and knowledge stock are determined by using the perpetual inventory method; i.e.

$$
K_{t}=(1-\varphi) K_{t-1}+I_{K, t}
$$

and

$$
R D_{t}=(1-\chi) R D_{t-1}+I_{R D, t}
$$

where $\varphi$ and $\chi$ are the depreciation rates with respect to the capital and knowledge stock, respectively, while $I_{K, t}$ and $I_{R D, t}$ are defined as the (annual) investments in both stocks. With regard to the capital stock a depreciation rate of 5\% and with regard to the knowledge stock we assume a depreciation rate of $15 \%$ is taken into account. ${ }^{18}$

The indirect knowledge stocks are constructed using the technology flow matrix. The domestic indirect knowledge stock for sector $k$ is defined as

$$
I R D_{k}=\sum_{j} \omega_{j k} R D_{j}\left(1-m_{j}\right)
$$

and the foreign knowledge stocks for the same sector are defined as

$$
\begin{aligned}
& I R E U_{k}=\sum_{E U} \sum_{j} \omega_{j k} R D_{E U j} s_{E U j} m_{j}, \\
& I R O T_{k}=\sum_{O T} \sum_{j} \omega_{j k} R D_{O T j} s_{O T j} m_{j}
\end{aligned}
$$

\footnotetext{
${ }^{18}$ The initial capital and knowledge stocks are defined in the following manner $K_{0}=\left(I_{K, 1}\right) /(\varphi+0.05)$ and $R D_{0}=$ $\left(I_{R D, 1}\right) /(\chi+0.05)$. This is in line with definitions suggested in Griliches (1980).
} 
and

$$
I R F_{k}=\sum_{F} \sum_{j} \omega_{j k} R D_{F j} s_{F j} m_{j}
$$

where $I R E U+I R O T=I R F$. In these four equations $\omega_{j k}$ is defined as the part of R\&D performed by sector $j$ that spills over to sector $k$ and $m_{j}$ is the import share of sector $j .{ }^{19}$ In equations (5a), (5b) and (5c) EU, OT and $F$ are the number of trading partners that are taken into consideration. Due to data limitations, these partners included in set $F$ are Australia, Canada, Denmark, Finland, France, Germany, Italy, Japan, Norway, Spain, Sweden, UK and US. EU-countries are included in the set $E U$, while non-EU-countries are put in set $O T$. The variable labelled $s_{F j}$ gives the import share of sector $j$ in the Netherlands from country $F$.

Finally, equation (1a) and (1b) are rewritten in log-form in order to perform the estimations. This is done by dividing every variable, except IRD, IREU, IROT and IRF, by $L$ and subsequently taking logarithms. This leads to equations (6a) and (6b) which are subject to further econometric estimation:

$$
y-l=a+\alpha(k-l)+\lambda l+\rho(r d-l)+\delta \text { ird }+ \text { eireu }+ \text { oirot }
$$

and

$$
y-l=a+\alpha(k-l)+\lambda l+\rho(r d-l)+\delta i r d+\phi i r f
$$

to which an error term is added. ${ }^{20}$

The database constructed to estimate equation (6a) and (6b) is a panel database. Hence we use the so-called 'within' regression method. This method is in essence an OLS-regression in which per sector the average value of the variable is subtracted from the variable's actual value. The

\footnotetext{
${ }^{19}$ It is important to note that the diagonal of the technology flow matrix with respect to the calculation of the domestic knowledge stock is put at zero to exclude the problem of multicollinearity, i.e. $\omega_{j j}=0$.

${ }^{20}$ Note that $\lambda=\alpha+\beta+\rho-1$. If $\lambda=0$ we observe constant returns to scale with regard to sector $j$ 's own production factors.
} 
reason to use the 'within' regression method is that it gives a strong and comprehensive picture of the development over time; in this case 1973-1995. ${ }^{21}$ The results of the regressions are displayed in Table 1.

\section{Table 1}

Estimation Results

\begin{tabular}{|c|c|c|c|c|c|c|c|c|}
\hline & $\alpha$ & $\rho$ & $\delta$ & $\phi$ & $\epsilon$ & $\sigma$ & $\lambda$ & $\mathbf{R}^{2}$ adj. \\
\hline & $k-l$ & $r d-l$ & ird & $i r f$ & ireu & irot & $l$ & \\
\hline \multirow[t]{2}{*}{1} & 0,402 & 0,060 & & & & & 0,050 & 0,424 \\
\hline & $(12,184)$ & $(2,423)$ & & & & & $(0,944)$ & \\
\hline \multirow[t]{2}{*}{2} & 0,311 & 0,075 & 0,155 & & & & 0,064 & 0,438 \\
\hline & $(7,471)$ & $(3,001)$ & $(3,507)$ & & & & $(1,234)$ & \\
\hline \multirow[t]{2}{*}{3} & 0,230 & 0,064 & & 0,153 & & & $-0,012$ & 0,475 \\
\hline & $(5,675)$ & $(2,687)$ & & $(6,720)$ & & & $(-0,220)$ & \\
\hline \multirow[t]{2}{*}{4} & 0,186 & 0,072 & 0,100 & 0,142 & & & 0,002 & 0,480 \\
\hline & $(4,139)$ & $(3,028)$ & $(2,216)$ & $(6,097)$ & & & $(0,047)$ & \\
\hline \multirow[t]{2}{*}{5} & 0,196 & 0,067 & & & 0,159 & 0,030 & $-0,039$ & 0,487 \\
\hline & $(4,579)$ & $(2,867)$ & & & $(4,233)$ & $(0,975)$ & $(-0,747)$ & \\
\hline \multirow[t]{2}{*}{6} & 0,169 & 0,073 & 0,068 & & 0,142 & 0,035 & $-0,240$ & 0,489 \\
\hline & $(3,772)$ & $(3,068)$ & $(1,534)$ & & $(3,611)$ & $(1,148)$ & $(-0,467)$ & \\
\hline
\end{tabular}

Note: t-values in brackets

\footnotetext{
${ }^{21}$ For an elaboration on this regression method (and other regression methods) we refer the reader to Greene (1997).
} 
First of all results of regressions are presented without taking into account knowledge spillovers. This results in a coefficient for $\alpha$ of approximately $40 \%$, which is above the for the Netherlands usual value of $30 \%$. The effect of the knowledge stock (Table 1, second line) on labour productivity is positive and statistically significant: $6 \%$ (t-value 2,423). If domestic indirect knowledge spillovers are introduced, it turns out that the capital/labour ratio is in line with the expected $30 \%$. Note that the elasticities of the domestic knowledge stock are twice as large as the elasticities of the sector's own knowledge stock, indicating the importance of the public knowledge basin for labour productivity. This observation indirectly supports the scope for government intervention by means of e.g. university funding and providing education to develop skills along the lines of the arguments presented in Figure 1.

In the third regression -- in which the sum of knowledge spillovers from both the EU and the rest of the world $(I R F)$ to the Netherlands is taken into account -- a significant effect of imported knowledge on labour productivity is found: the coefficient $\phi$ has a value of 0.153 with a significant t-value of 6,720. Moreover, this effect is larger than the effect of the sector's own knowledge stock on labour productivity. Next, we estimate the whole model. The results (Table 1, fourth line) show that knowledge spillovers are of central importance to Dutch manufacturing. The spillover coefficients are of great prominence in explaining the accumulation of income and labour productivity.

An interesting point to investigate is whether foreign knowledge spillovers basically the a result of EU knowledge spillovers or not. The fifth and sixth regression in Table 1 show that knowledge spillovers from the EU are highly significant. The coefficients $\epsilon$ have a value of $15.9 \%$ and $14.2 \%$, respectively, pointing at significant spillovers from the EU-countries to the Netherlands. Knowledge spillovers from the rest of the world to the Netherlands turn out to be insignificant, pointing towards the importance of the EU as a knowledge block in the world economy, for a small open EU economy such as the Netherlands.

Furthermore, the results presented here suggest that for a small economy such as the Netherlands, 
these benefits are primarily derived from R\&D efforts performed in other EU-countries. ${ }^{22}$ These results are in line with the estimation results of Griliches (1992), Verspagen (1997b) and Keller (1998); Keller finds that benefits derived from foreign R\&D in the same industry are in the order of 50 to $95 \%$ of the productivity effect of own R\&D.

In general, the results stress the importance of $R \& D$ efforts and $R \& D$ spillovers for productivity growth. However, the results also suggest that knowledge easily spills over from one sector and one country to another, pointing to the difficulties in internalising the fruits of innovating activities. Such internalisation within an industry cluster can be enhanced through the setting up of institutions, aiming at internalising some of the these knowledge spillovers in particular those linked to sectoral R\&D efforts.

Both Romer (1993) and Weder and Grubel (1993) have shown that, from a Coasean economics point of view, there exists a tendency for the creation of institutions to reduce the possible under-investment in $R \& D$ by reducing the size of the externalities and hence the need for government policies to correct the market failure caused by the non-rivalness characteristics of knowledge. Weder and Grubel investigate three different institutions based on Porter (1990): (i) associations, that function like a club; (ii) conglomerates, consisting of firms that by output or input characteristics belong to different industries but take advantage of joint R\&D interests; and (iii) industry clusters, that profit from a variety of positive feedback loops and spillovers which individual companies enjoy due to the activities of other firms in the cluster. Romer (1993) on the other hand pleas for improving collective action, including institutional development and learning, to enhance economic growth. What he has in mind is a so-called limited liability corporation, an invention that would not have been viable without the emergence of supporting regulatory and legal institutions. In both analyses the selection of institutions, however, has to be left to the market because the market is best capable of selecting the channels and institutions that stimulate the effort put in the process of new inventions that ultimately drive economic growth.

\footnotetext{
${ }^{22}$ Note that in all four regressions $\lambda=0$ cannot be rejected.
} 


\section{Policy Conclusions}

From the outset the European economic integration process was accompanied by a set of specific industrial and technological policies, fostering intra-European cooperation in the field of pre-competitive $R \& D$, university researchers, students, and various support programmes for particular technology fields: the so-called framework programmes and other related technological support programmes. Interestingly, these policies that aimed at strengthening European competitiveness in high tech sectors have probably been most successful in some of the 'big science' RTD areas, where essential scale economies could indeed be achieved. In most other areas though, the EU resources available when compared to national resources were too limited to make any impact in shifting or redirecting countries' own national priorities in supporting investment in knowledge accumulation (both education, training and research). At the same time, the international accessibility to codified knowledge increased dramatically through the use of ICTs. While support for intra-European research collaboration might still be welcome in many cases, the essential research collaboration will often be of a much more global nature, going well beyond the European borders. There could even be a case of knowledge acquisition 'diversion', the intra-European exchange having taken place at the expense of extra-European exchange. In the more basic research areas where open international access has always existed, such 'diversion' might have ultimately had little impact; in the more applied business research areas, it might well have been one of the factors behind the growth in so-called 'strategic alliances' between large European, US and Japanese firms trying to source knowledge more globally while at the same time benefiting from various national or supra-national support programmes. It is what could be called the European technology policy paradox: as Europe invested in intra-European research, in the collaboration and exchange of scientific knowledge among European scientists, or even in the technological strengthening of the competitive potential of European firms, the advantages of such geographically 'bounded' collaboration have increasingly become marginal, given the dramatically increased opportunities for the fast exchange of information and cooperation.

As we saw in the second section of this paper, there is now growing recognition that knowledge, both as an input and output, is central to the process of growth and wealth accumulation. As a 
recent OECD document (OECD (1996)) puts it: "A Knowledge in all it forms plays today a crucial role in economic processes. Intangible investment is growing much more rapidly than physical investment. Firms with more knowledge are winners on markets. Nations endowed with more knowledge are more competitive. Individuals with more knowledge get better paid jobs. This strategic role is at the root of increasing investments by individuals, firms and nations in all forms of knowledge." In short, most contemporary developed economies are and have increasingly become 'knowledge-based'.

NGT has recognized the crucial role of knowledge accumulation in the growth process. Without technological change, capital accumulation will not be sustained -- its marginal productivity declining -- and the equilibrium (per capita) growth of the economy will inexorably tend towards zero. It are the inventions of new machines and intermediate goods which provide the opportunities for new investment. Thus, as has been shown in many empirical studies, the efficiency gains following the introduction, diffusion and continuous improvements of new production processes, have been the major factor behind the rise in income over the post-war period in most developed economies.

The recognition of the importance of this broader notion of knowledge accumulation is challenging the traditionally segmented 'market failure' policy approach to S\&T support. As argued in section 2, from this broader approach policies with regard to technological chance encompass not just R\&D, but the whole spectrum of scientific and technological activities from invention to diffusion, from basic research to technological mastery. Such a view of technological change rejects the orthodox economics definition of technological capabilities in terms of 'information' with the connotation that industrial technology is like a recipe; understood by particular individuals and readily articulatable and communicable from one individual to another with the requisite background training. From a Schumpeterian perspective, what is written down -- the recipe, the textbook discussion, the patent -- provides a start, but only in the sense that a recipe provides a start. Knowing how to produce a product, is as much experienced tacit skill as articulatable knowledge. And contrary to the implicit general theory the tacit skills of one 'skilled in the art' are not 'interchangable': who works with the recipe makes a difference. 
But as argued in section 3, the more open, international technology environment of the end of this Century confronts most EU economies with new, fundamental challenges in the science, technology and innovation area, not in the least because of the crucial importance of sectoral and international knowledge spillovers. While EU spillovers appear from this perspective, as was illustrated in the case of The Netherlands essential, it does not imply of course that current technology institutions both in individual EU Member Countries and at the EU supra-national level, in their priority setting, design and implementation are particularly well suited and effective in responding to some of the new policy challenges identified in section 2 .

It is not the place here to try to answer this question. Rather to highlight, that in the end little is known about the effectiveness of the various science, technology and innovation policies and institutions implemented in the EU. Whereas at the national level many detailed analyses have been carried out evaluating and monitoring particular policy instruments and hence assisting policy makers in continuous institutional learning, we are particularly concerned with the response (or rather lack of response) of European technology policies to the new policy challenges raised above.

Thus, and keeping in mind that this is by and large a non-exhaustive list, the question can be raised whether the concept of 'pre-competitive research', popular in many European S\&T policies, is still of any relevance to the more systemic way in which S\&T appear to interact today, or whether the 'pre-competitive' concept has actually reinforced the emergence of a European 'research paradox' with public support for those research activities for which applications could not be thought of. Similarly, the question can be raised whether the 50/50 principle of public/private support has not practically automatically led to the substitution of private $R \& D$ funding of the least profitable $R \& D$ activities, furthest removed from individual firms = core $\mathrm{R} \& \mathrm{D}$ and competitive strength areas; just as the $100 \%$ principle in the case of universities or public research laboratories might have led to substitution of national funds for EU Framework Programme funds. Similarly, and interacting with the broader aims of social cohesion, the question can be raised whether the large flow of R\&D Community funding to the peripheral countries, representing in some countries such as Greece already $60 \%$ of total business enterprise R\&D efforts, will bring about an indigenous S\&T development in those countries. Finally, the 
question can be raised whether the desire for European networking, collaboration and coordination in the S\&T area, is not reinforcing what are already national strongholds in S\&T, rather than raising the overall level of European S\&T.

At a more general level, the question can be raised whether European technology policies should not be fundamentally redesigned. We would argue that within the emerging framework of a European monetary union, it will be essential to have new technology policies aimed at increasing mobility of researchers across Europe. Characteristic of European research (and in particular publicly funded research) is indeed its fragmented nature and small country bias with a multitude of relatively small research institutes being spread over a very widespread field of different disciplines.

A European technology policy might hence start to focus explicitly on the various barriers to such mobility. One might think e.g. of an explicitly mobility related European status for European expatriate research personnel comparable to the status of European civil servants and providing a common, harmonized social security, pension and fiscal system to such European researchers. In emerging 'Euroland', labour market fragmentation particularly of high skilled labour qualifications is likely to be most damaging for economic growth and competitiveness.

The need for European institutional development and learning to internalize R\&D efforts might hence take many different forms, going well beyond traditional forms or arguments about industrial technology clustering, but including more than ever a specific international European dimension, so as to enhance the missing economies of scope and scale. In this respect an international, open version of Coasean economics might give us some insights into the sort of international European industry institutions likely to emerge to more fully exploit the gains from joint European R\&D. Now that EU integration is entering its ultimate economic and monetary union phase, we conclude that EU policy should start to reassess the needs for a new technology policy institutional framework more directly aimed at removing the remaining European barriers to knowledge distribution. 


\section{References}

Aghion, P. and P. Howitt (1988), Growth and Cycles through Creative Destruction, MIT Mimeo, Cambridge MA.

Aghion P. and P. Howitt (1992), 'A Model of Growth through Creative Destruction,' Econometrica, 60, pp. 323-351.

Aghion, P. and P. Howitt (1998), Endogenous Growth Theory, Cambridge MA, MIT Press.

Arrow, K. J. (1962), 'The Economic Implications of Learning by Doing,' Review of Economic Studies, 29, pp. 155-173.

Bernstein, J. I. and P. Mohnen (1991), 'Price-Cost Margins, Exports and Productivity Growth with an Application to Canadian Industries,' Canadian Journal of Economics, 24, pp. 638-659.

Bernstein, J. I. and P. Mohnen (1998), 'International R\&D Spillovers between US and Japanese R\&D Intensive Sectors,' Journal of International Economics, 44, pp. 315-338.

Caballero, R. J. and A. B. Jaffé (1993), 'How High Are the Giant's Shoulders: An Empirical Assessment of Knowledge Spillovers and Creative Destruction in a Model of Economic Growth,' NBER Macroeconomics Annual, Cambridge MA, MIT Press.

Caracostas, P. and L. L. G. Soete (1997), 'The Building of Cross-border Institutions in Europe, Towards a European System of Innovation?,' in: C. Edquist, Systems of Innovation, London, Pinter, pp. 395-420.

Coe, D. T. and E. Helpman (1995), 'International R\&D Spillovers,' European Economic Review, 39, pp. 859-887.

Coe, D. T., E. Helpman and A. Hoffmaister (1997), 'North-south R\&D Spillovers,' Economic Journal, 107, pp. 134-149.

David, P. A. and D. Foray (1995), 'Accessing and Expanding the Science and Technology Knowledge Base,' STI Review, 16, Paris, OECD.

Ergas (1987), 'Does Technology Policy Matter?', in: B. Guile and H. Brooks (eds.), Technology and Global Competition, Washington, National Academy Press.

EU (1996), The Green Book on Innovation, Brussels, EU.

EU (1997), Second European Report on S\&T Indicators, Brussels, EU.

Freeman, C. (1987), Technology Policy and Economic Performance: Lessons from Japan, 
London, Pinter.

Freeman, C. and L. L. G. Soete (1997), The Economics of Industrial Innovation, Third Edition, London, Pinter.

Greene, W. H. (1997), Econometric Analysis, Third Edition, New Jersey, Prentice Hall.

Griliches, Z. (1980), 'R\&D and Productivity Slowdown,' American Economic Review, 70, pp. 343-348.

Griliches, Z. (1984), R\&D, Patents and Productivity, Chicago, University of Chicago Press.

Griliches, Z. (1992), 'The Search for R\&D Spillovers,' Scandinavian Journal of Economics, 94, pp. s29-s47.

Griliches, Z. (1998), R\&D Spillovers, Econometric Evidence, Chicago, University of Chicago Press.

Grossman, G. M. and E. Helpman (1991), Innovation and Growth in the Global Economy, Cambridge MA, MIT Press.

Johnson, B. and B. Gregersen (1995), 'Systems of Innovation and Economic Integration,' Journal of Industry Studies, 2, pp. 1-18.

Keller, W. (1998), Trade and the Transmission of Technology, NBER working paper nr. 6113, Washington D.C.

Lichtenberg, F. (1992), Corporate Takeovers and Productivity, Cambridge MA, MIT Press.

Lichtenberg, F. and D. Siegel (1991), 'The Impact of R\&D Investment on Productivity: New Evidence Using Linked R\&D-LRD Data,' Economic Inquiry, 29, pp. 203-229.

Lundvall, B.-Å. (1992), National Systems of Innovation: An Analytical Framework, London, Pinter.

Malerba F. and L. Orsenigo (1993), 'Technological Regimes and Firm Behaviour,' Industrial Corporate Change, 2, pp. 45-71.

Mowery, D. (1992), 'Survey of Technology Policy,' in: P. Stoneman (ed.), Handbook of the Economics of Technical Change, Amsterdam, Elsevier.

Nelson, R. R. (1959), 'The Simple Economics of Basic Scientific Research,' Journal of Political Economy, 67, pp. 297-306.

Nelson, R. R. (ed.) (1993), National Systems of Innovation: A Comparative Study, Oxford, Oxford University Press.

Nelson, R. R. (1999), Tinbergen Lecture, De Economist, Forthcoming 1999. 
Nelson, R. R. and S. Winter (1982), An Evolutionary Theory of Economic Change, Cambridge MA, Harvard University Press.

OECD (1995), MSTI Database, Paris, OECD.

OECD (1996), Technology, Productivity and Job Creation, Vol. I and II, The OECD Job Strategy, Paris, OECD.

Oltra (1998), Industrial Dynamics and Diversity in Schumpeterian Technological Regimes, Paper presented at the ETIC Conference, Strasbourg, 16-17 October.

Porter, M. E. (1990), The Competitive Advantage of Nations, London, Pinter.

Romer, P. M. (1990), 'Endogenous Technological Change,' Journal of Political Economy, 98, pp. s71-s102.

Romer, P. M. (1993), 'Implementing a National Technology Strategy with Self-Organising Industry Investment Boards,' Brooking Papers on Economic Activity, pp. 345-390.

Segerstrom, P.S., T. Anant and E. Dinopoulos (1990), 'A Schumpeterian Model of the Product Life Cycle,' American Economic Review, 80, pp. 1077-1092.

Soete, L. L. G. and A. Arundel (1993), An Integrated Approach to European Innovation and Technology Diffusion Policy: A Maastricht Memorandum, Brussels, EU.

Soete, L. L. G. and R. Turner (1984), Technology Diffusion and the Rate of Technical Change, Econmic Growth and the Structure of Long-Term Development, New York, St. Martin's Press.

Van Dijk, M. (1998), Technological Regimes and Industrial Dynamics: The Evidence from Dutch Manufacturing, MERIT Mimeo, Maastricht.

Van Meijl, H. (1995), Endogenous Technological Change: The Case of Information Technology, PhD Thesis, MERIT, Maastricht University, Maastricht.

Verspagen, B. (1995), 'R\&D and Productivity: A Broad Cross-Section Cross-Country Look,' Journal of Productivity Analysis, 6, pp. 117-135.

Verspagen, B. (1997a), 'Measuring Inter-Sectoral Technology Spillovers: Evidence from the European and US Patent Office Databases,' Economic Systems Research, 9, pp. 49-67.

Verspagen, B. (1997b), 'Estimating International Technology Spillovers Using Technology Flow Matrices,' Weltwirtschaftliches Archiv, 133, pp. 226-248.

Weder, R. and H. G. Grubel (1993), 'The New Growth Theory and Coasean Economics: Institutions to Capture Externalities,' Welwirtschaftliches Archiv, 129, pp. 488-513. 
Winter, S. (1984), 'Schumpeterian Competition in Alternative Technological Regimes,' Journal of Economic Behaviour and Organization, 5, pp. 287-320.

Wolff, E. (1995), 'Technology and the Demand for Skills,' STI Review, 16, Paris, OECD. 